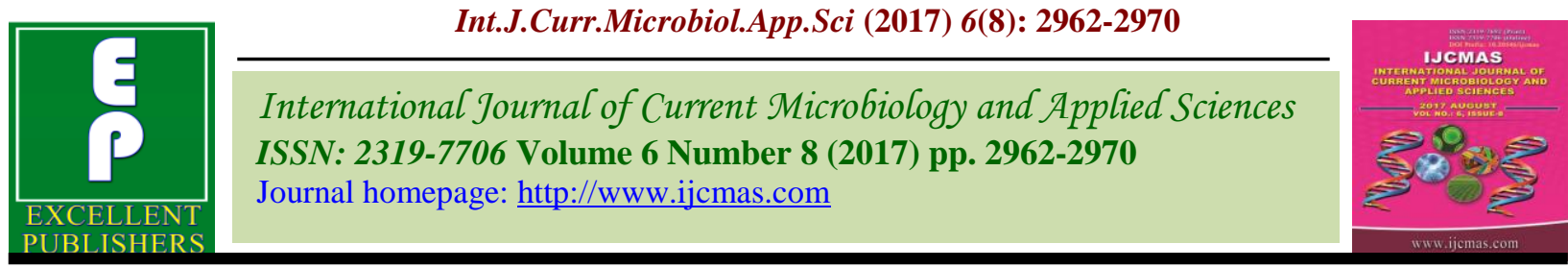

Original Research Article

https://doi.org/10.20546/ijcmas.2017.608.355

\title{
Seasonal Variations of Zooplankton Community in Selected Ponds at Lake Kolleru Region of Andhra Pradesh, India
}

\author{
P.V. Krishna* and Hemanth Kumar \\ Department of Zoology and Aquaculture, Acharya Nagarjuna University, \\ Nagarjuna Nagar- 522 510, Andhra Pradesh, India \\ *Corresponding author
}

\begin{tabular}{l} 
Key w o r d s \\
Biodiversity, \\
Zooplankton, \\
Perennial ponds, \\
Physicochemical \\
parameters. \\
Article Info \\
$\begin{array}{l}\text { Accepted: } \\
\text { 23 June } 2017 \\
\text { Available Online: } \\
\text { 10 August } 2017\end{array}$ \\
\hline
\end{tabular}

Keywords

Biodiversity, Zooplankton, Perennial ponds, Physicochemical parameters.

Article Info

Accepted:

Available Online:

10 August 2017

\section{A B S T R A C T}

Zooplankton holds a key position in the food web as it was directly related to the consumption of organic energy produced by phytoplanktonic photosynthesis and then by transforming it to the higher tropical levels of hetirotropes such as fish. Some zooplankton population disappeared at a specified period and reappeared during other period. This disappearance may be due to the fact that some species occur in spores, under favorable conditions spore germinate and appear as zooplankton. Plankton diversity and physicochemical parameters of water are important criteria for evaluating the suitability of water for culture practices. Therefore, structure of different fish food organisms assumes greater significance to fisheries management. Indiscriminate exploitation of Lake Kolleru has been evidently resulted in the depletion of fish fauna and it leading to folding and other negative consequences at surrounding area. In this study, we tried to assess zooplankton richness, evenness and diversity to observe the state of pond water in the study area. A total number 16 species recorded with 9 Rotifera, 3 Cladocera and 4 Copepods. In the rotifers the genus Brachionus is the dominant group.

\section{Introduction}

Water is one of the most natural resources for all the living organisms, weather unicellular or multi cellular, since it is required for various domestic purposes irrigation, power generation and industries. In a freshwater system, the zooplankton forms are important group and constitute basic link of the food chain. Planktons are very sensitive to the environment they live in and any alteration in the environment leads to the changes in the plankton communities in terms of tolerance abundance, diversity and dominance in the habitat (Mathivonam, 2007). The planktonic study is a very useful tool for the assessment of water quality in any type of water body and also contributes to an understanding of the basic nature and general economy of the water body. Plankton occurs in all natural water as well as in artificial impoundments like ponds, tanks, reservoirs, irrigation cannels, etc. Plankton being the primary producer from the lowest trophic level in the food chain of fresh water ecosystem and plays a key role in fish culture. The number ad species of plankton serves to determine the quality of water body. The structure of aquatic community is important in monitoring the water quality. The density and diversity of 
the plankton are greatly influenced by the different physicochemical parameters of water (Wetzel, 1975). Species composition of the plankton community is an efficient indicator of water quality. Zooplankton consist of Protozoans, Cladocera, Copepod, Rotifers, etc. which may serve as indicators of water quality. The zooplanktons play an important tropic level in the aquatic ecosystem as they constitute the most import link in the energy transfer between phytoplankton and higher aquatic fauna (Iloba, 2002). In ecologically zooplankton is one of the most important biotic components influencing all the functional aspects of an aquatic ecosystem such as food chains, food webs, energy flow and cycling of matter (Park and Shin, 2007).

Aquatic biodiversity is threatened primarily by human abuse and management of both living resources and the ecosystem that support them. Most of the ponds are getting pollution due to domestic waste, sewage, industrial, aquatic and agricultural effluents. The requirement of water in all lives, from microorganisms to human beings is a serious problem of present day because of water resources have reached to a point of crisis due to unplanned urbanization, industrialization and other manmade activities. Many biotic and abiotic processes contribute to variability in plankton diversity in aquatic ecosystems. Seasonal requirement of plankton assemblages are closely linked to seasonal changes in temperature, external hydraulic, nutrient loads and light availability (Malten $e t$ al., 1991), other process acting on as time periods on days to week, like meteorological and hydrological events (Guillermo, 2009) and also pollution stress on them (Raja et al., 2008). Zooplankton diversity responds rapidly to changes in the aquatic environment. Several zooplankton species are served as bio indicators (Ahmad et al., 2011, Mola, 2011). A number of studies have been carried out on ecological condition of freshwater bodies in various parts of India (Singh et al., 2002; Smith et al., 2007; Rajagopal et al., 2010), but coastal Andhra Pradesh particularly Kolleru area the ecological studies of freshwater body is very scanty. However, information on relation between physicochemical parameters and planktonic fauna is very limited (Ahmad and Siddiqui, 1995, Choudhary and Singh, 1999). So the present investigation attempts to study the zooplankton species richness, diversity and evenness, in relation between physicochemical parameters in a perennial pond at Lake Kolleru area.

\section{Materials and Methods}

\section{Study area}

Lake Kolleru in Andhra Pradesh is an important natural shallow freshwater lake formed as a basin between the gradually growing deltas of rivers Godavari and Krishna. It is situated between a latitudes $16^{\circ}$ $32^{\prime}$ and $16^{\circ} 47^{\prime} \mathrm{N}$ and Longitudes $81^{\circ} 4^{\prime}$ and $81^{\circ} 22^{\prime} \mathrm{E}$. The present study pond situated near Budamaru near Kaikaluru. The pond is shallow (depth 0.90 to $1.78 \mathrm{~m}$ ) covering an area of about 2.5 ha. The source of replenishment is sewage from surrounding area. Pond contains mostly sand, lose mud, decayed litter deposit.

\section{Collection of samples}

The pond survey was carried out from August 2012 to July 2013. Water samples were collected from periodically every fortnight of the selected pond during the early hours between 8.00 to $10.00 \mathrm{am}$. The data was articulated seasonally as northeast monsoon (December-February); summer (March-May); southwest monsoon (June-September) and post monsoon (October-November). The plankton samples were collected by filtering by 50 liters of water through standard 
plankton net (77 meshes bolting sink) and concentration samples fixed in $5 \%$ of formalin.

\section{Physicochemical analysis}

Temperature was recorded with centigrade thermometer. The $\mathrm{pH}$ of water samples was measured by using $\mathrm{pH}$ meter. The remaining physicochemical parameters of water were done according to standard methods (APHA, 1985).

\section{Biological analysis}

Zooplankton species identification was done by the help of standard reference (Alfred et al., 1973). The quantitative analysis of planktonic organisms was carried out using Sed Wick Rafter plankton counting cell in according to Welch (1948). ShannonWeaver's species diversity index: This was proposed by Shannon and Weaver (1949) as measure of information and their diversity across the different pond sampled. ShannonWeaver $(\mathrm{H})$ is commonly used to characterize species diversity in a community. This index account for both abundance and evenness of the species presents. The proportion of species $(P i)$ is calculated and then multiplied by the natural logarithm of this proportion $(\log (P i))$.

As per the formula given by Shannon and Weaver (1949):

$$
\begin{aligned}
& H=-\sum(\mathrm{ni} / \mathrm{N}) \log (\mathrm{ni} / \mathrm{N}) \\
& \text { Or } \\
& H=-\sum P i \log (P i)
\end{aligned}
$$

Whereas,

$\mathrm{H}=$ Shannon's -Wiener's index of species diversity in individuals. ni $=$ Total number of individuals

$\mathrm{N}=$ Total number of individuals of all species.

$\mathrm{Pi}=$ Importance of probability for each species (ni/N).

\section{Results and Discussion}

Physicochemical parameters of water body serves as measure of water quality. Changes in the source of water and rainfall affect physicochemical parameters of water, which also affects the biomass of the aquatic organisms. The physico-chemical parameters of water were given in table 1 .

The physico-chemical parameters of zooplankton communities together form a comprehensive ecosystem and there is interaction between the zooplankton and phytoplankton. These interactions are directly or indirectly subjected to the complex influences (Basawarajeshwari, et al., 2015). Zooplankton was represented by Rotifera, Cladocera and Copepods. Among the plankton Rotifer was dominated and followed by Copepods and Cladocerans. In the Rotifera five genera and nine species were observed. Among the Rotifera genus Brachions is the dominant group.

In the Copepods represent three genera and four species and also Cladocerans found 3 genera and 3 species. During the study period quantitative and qualitative variations of zooplankton was observed (Table 2). Zooplankton richness observed in the both monsoon periods whereas lowest number in the summer and post monsoon period. Similar results observed by (Mukherjee, 2011). In the ecosystem, zooplankton plays a main role as they consume the primary producers (phytoplankton) and form a major food source for tertiary producers. 
Zooplankton considered as the basic principle natural fish food for young and some adults of organisms, which support fish production (ElSerafy et al., 2009). The zooplankton assemblage inhabiting freshwater, mostly comprises representative of protozoa, Coelenterata, Rotifera, Gastrotricha, Bryozoa and Arthropoda. The zooplanktons often respond immediately to environmental changes because most of the species have short generation times. Epifanio and Garvine (2001) studied by the variations of their spatial distribution, based on different factors.

The higher population density of the zooplankton is during the both monsoon periods while low population density observed in the summer and post monsoon. Among the plankton Roitifera is dominated. The zooplankton populations dominated by rotifers in the wet season are observed by Egborge (1981).

The high population density in the monsoon period may be as a result of abundant food sources from the runoff. Rocha et al., (1999) reported that the increase of primary production (phytoplankton) is accompanied by increase in zooplankton abundance. Muylaert et al., (2003) observed that the zooplankton abundance frequently reach their peak during the wet season in ponds. Besides food source, low predation rate by fish during wet season caused by plankton increased breading activity, could support by high population density of zooplankton (Ikpi et al., 2013).

In the present observations of the ShannonWeaver's index of the species in individuals of plankton in the pond fauna was recorded. The diversity index of zooplankton in different seasons in the different seasons in the study area was given in table 2. The species diversity index value are 1.640 (N.E. Monsoon), 1.293 (Summer), 1.408 (S.W. monsoon) and 1.633 (Post-monsoon). The biodiversity of monsoon higher in the monsoon period both northeast and southwest monsoons followed by post monsoon. Where minimum values recorded in the summer.

High density of zooplankton diversity during monsoon period may be attributed to inflow of rainy water and favorable environment conditions. Ikpi et al., (2013) reported that the seasonal variation in zooplankton condition could larger be due to the Rotifera which normally constitute major food items of larger zooplankton.

The air temperature ranged from $22-34{ }^{\circ} \mathrm{C}$ and highest temperature recorded in the month of April, 2016. Temperature is one of the important environment factors, since it is influencing the distribution of fauna and flora. Gaikwad (2008) reported that water temperature $13.5-32^{\circ} \mathrm{C}$ is to be suitable for the development of the planktonic organisms. Rainfall ranged between 1.64 to $489.6 \mathrm{~mm}$ and rain did not occur during months of December 2012, January 2013 and March 2013. Rainfall is the important cyclic phenomena in tropical countries.

In the present results the peak values of rainfall were recorded in the month of July, 2013(middle of south west monsoon) and lowest recorded in the month of February, 2016. The India in influenced by two monsoon i.e. south west monsoon and northwest monsoons. Transparency ranged between 28-34 cm and highest reading recorded month of August 2015, due to the distribution effect of rains and sediment settlement after south west monsoon season.

The lowest value of reading observed during summer (March, April, and May, 2013) which might be due to evaporation of water in the pond, which may cause concentration of dissolved solids at high temperature. 
Table.1 Physico-chemical parameters of the pond water in different months at study area

\begin{tabular}{|l|l|l|l|l|l|l|l|l|l|l|}
\hline $\begin{array}{l}\text { Study } \\
\text { Period }\end{array}$ & Tem & Tr. & DO & pH & TA & TH & NO $_{2}$ & NO $_{3}$ & OP & Ir. \\
\hline Aug.2015 & 26 & 34 & 5.9 & 7.4 & 165 & 176 & 0.039 & 0.41 & 0.51 & 0.38 \\
\hline Sep. 2015 & 28 & 28 & 5.9 & 7.6 & 155 & 125 & 0.028 & 0.56 & 0.61 & 0.42 \\
\hline Oct. 2015 & 23 & 30 & 5.6 & 8.0 & 145 & 165 & 0.063 & 0.42 & 0.46 & 0.38 \\
\hline Nov. 2015 & 24 & 32 & 5.8 & 8.6 & 150 & 120 & 0.064 & 0.56 & 0.53 & 0.43 \\
\hline Dec. 2015 & 24 & 32 & 4.5 & 7.8 & 160 & 115 & 0.076 & 0.48 & 0.67 & 0.36 \\
\hline Jan. 2016 & 23 & 30 & 5.0 & 8.8 & 135 & 145 & 0.073 & 0.53 & 0.57 & 0.28 \\
\hline Feb. 2016 & 22 & 32 & 4.4 & 8.2 & 150 & 190 & 0.068 & 0.60 & 0.63 & 0.32 \\
\hline Mar.2016 & 25 & 29 & 4.0 & 7.5 & 165 & 175 & 0.098 & 0.42 & 0.72 & 0.36 \\
\hline Apr.2016 & 26 & 33 & 4.0 & 7.6 & 175 & 155 & 0.056 & 0.48 & 0.59 & 0.51 \\
\hline May2016 & 30 & 33 & 4.1 & 7.8 & 170 & 145 & 0.074 & 0.43 & 0.48 & 0.30 \\
\hline Jun. 2016 & 30 & 28 & 5.2 & 8.2 & 155 & 165 & 0.076 & 0.51 & 0.42 & 0.38 \\
\hline Jul. 2016 & 32 & 32 & 5.6 & 8.0 & 140 & 155 & 0.063 & 0.53 & 0.58 & 0.36 \\
\hline
\end{tabular}

Tem: Temperature $\left({ }^{\circ} \mathrm{C}\right)$; $T r .:$ Transparency $(\mathrm{cm})$; DO: Dissolved Oxygen $(\mathrm{mg} / \mathrm{l}) ; \mathrm{pH}$ : Hydrogen ion concentration; TA: Total Alkalinity (mg/l as $\left.\mathrm{CaCo}_{3}\right)$; TH: Total hardness (mg/l as $\left.\mathrm{CaCo}_{3}\right) ; \mathrm{O}_{3}$ : Nitrate $(\mathrm{mg} / \mathrm{l}) ; \mathrm{NO}_{2}$ : Nitrite $(\mathrm{mg} / \mathrm{l})$; OP: Orthophosphates (mg/l); Ir.: Iron (mg/l).

Table.2 Biodiversity indexes of zooplankton in different seasons in the study area

\begin{tabular}{|c|c|c|c|c|}
\hline $\begin{array}{c}\text { ZOOPLANKTON } \\
\text { PECIES }\end{array}$ & $\begin{array}{l}\text { N.E. Monsoon } \\
(\mathrm{ni} / \mathrm{N}) \log \mathrm{ni} / \mathrm{N}\end{array}$ & $\begin{array}{c}\text { Summer } \\
(\mathrm{ni} / \mathrm{N}) \log \mathrm{ni} / \mathrm{N}\end{array}$ & $\begin{array}{l}\text { S.W. Monsoon } \\
(\mathrm{ni} / \mathrm{N}) \log \mathrm{ni} / \mathrm{N}\end{array}$ & $\begin{array}{l}\text { Post Monsoon } \\
(\mathrm{ni} / \mathrm{N}) \log \mathrm{ni} / \mathrm{N}\end{array}$ \\
\hline \multicolumn{5}{|l|}{ Rotifera } \\
\hline Brachionus caudatus & -0.154 & -0.154 & -0.153 & -0.132 \\
\hline B. falcatus & -0.146 & -0.094 & -0.147 & -0.103 \\
\hline B. calyciflorus & -0.152 & -0.134 & -0.155 & -0.154 \\
\hline B. forficula & -0.046 & -0.060 & -0.053 & -0.053 \\
\hline B. angularis & -0.035 & -0.027 & -0.040 & -0.067 \\
\hline Filinia longiseta & -0.052 & -0.058 & -0.064 & -0.107 \\
\hline Polyarthra remata & -0.007 & -0.007 & -0.013 & -0.015 \\
\hline Hexathra Sp. & -0.013 & - & -0.009 & -0.015 \\
\hline Keratella tropica & -0.109 & -0.090 & -0.087 & -0.142 \\
\hline Total & -0.714 & -0.624 & -0.721 & -0.788 \\
\hline \multicolumn{5}{|l|}{ Cladocera } \\
\hline Ceriodaphnia cornuta & -0.158 & -0.104 & -0.158 & -0.156 \\
\hline Moina micrura & -0.158 & -0.155 & -0.117 & -0.154 \\
\hline Diaphanosoma excisum & -0.152 & - & -0.155 & -0.154 \\
\hline Total & -0.468 & -0.259 & -0.43 & -0.464 \\
\hline \multicolumn{5}{|l|}{ Copepodes } \\
\hline Mesocyclops Sp. & -0.148 & -0.142 & -0.065 & -0.117 \\
\hline M. varicans & -0.145 & -0.038 & -0.057 & -0.024 \\
\hline Heliodiaptomus cinctus & -0.031 & -0.079 & -0.074 & -0.128 \\
\hline Diaptomus Sp. & -0.107 & -0.151 & -0.061 & -0.112 \\
\hline Total & -0.431 & -0.41 & -0.257 & -0.381 \\
\hline $\mathbf{H}=-\sum(n i / \mathbf{N}) \log n i / N$ & 1.640 & 1.293 & 1.408 & 1.633 \\
\hline
\end{tabular}

Abbreviations: N.E: North East; S.E: South West. 
Dissolved oxygen was observed in-between 4 to $5.9 \mathrm{mg} / \mathrm{l}$ and lowest recorded in month of September, 2012 (south west monsoon). Lower dissolved oxygen values obtained during dry season could probably due to higher temperatures during summer months. Dissolved oxygen distribution provides a good index of productivity and quality of environment. High oxygen consumption is indicative of higher photosynthetic efficiency and plankton production. Rajgopal (2010) reported that the abundance of phytoplankton which enriched water with high dissolved oxygen during photosynthesis. Dissolved oxygen is a sole of the physicochemical parameters of the water which need to keep the organisms alive and health of the water body of ecosystem (Madhusudhana and Krishna, 2013).

The $\mathrm{pH}$ value ranged between7.4-8.6 lowest recorded in the month of August (south west monsoons) whereas highest recorded in the month of January (North East monsoon). High value of $\mathrm{pH}$ may cause of low level of water and high photosynthesis resulting in high production of free $\mathrm{CO}_{2}$ during the equilibrium towards alkaline side (Siddamalayya and Pratima, 2008). Tanner (2005) reported that the $\mathrm{pH}$ range between 6.0 - 8.5 indicate median productive nature of reservoir and above 8.5 goes to highly productive. In the present, study months of January and November goes to above $8.5 \mathrm{pH}$ which indicates that the water is a highly production of zooplankton population. Total alkalinity of present results is in between 120 to $162 \mathrm{mg} / \mathrm{l}$. Maximum recorded in the month of April whereas minimum in the month of December. Similar results observed by Narasimha Ramulu and Benarjee (2013) at Nagaram tank of Warangal. The total hardness of water fluctuation ranged from 135-178 (mg/l). Maximum recorded in the month of April and minimum recorded in the month of February. The minimum during the month of February may be due to deposition of Calcium and Magnesium salts in that season (Narsimha Ramulu and Benarjee, 2013).

Nitrogen is essential for leaving organisms as an important constituent of proteins, including genetic material. Plants and microorganisms convert inorganic nitrogen to organic forms. In the environment inorganic nitrogen occurs in a range of oxidation status as Nitrate $\left(\mathrm{NO}_{3}\right)$ and Nitrite $\left(\mathrm{NO}_{2}\right)$, the ammonium ion $\left(\mathrm{NH}_{4}{ }^{+}\right)$ and molecular Nitrogen $\left(\mathrm{N}_{2}\right)$. It is under goes biological and non-biological transmission in environment as part of nitrogen cycle. In the present study Nitrite in-between 0.028-0.098 $\mathrm{mg} / \mathrm{l}$; Nitrate in-between 0.41 to $0.60 \mathrm{mg} / \mathrm{l}$ and Ammonia goes to 0.31 to $0.64 \mathrm{mg} / \mathrm{l}$ in the culture pond.

Iron is an important element for almost all living species. Its environmental impacts on physiological and ecological aspects of aquatic organisms are focus on limnological studies (Xing and Liu, 2011). The variations of Iron profoundly influence the structure and function of aquatic ecosystem (Shaked et al., 2004). In the present study Iron ranges from 0.28 to $0.51 \mathrm{mg} / \mathrm{l}$ lowest record in the month of January and (0.28) and highest recorded in the month of April, 2013.

According to Sousa et al., (2008) changes in water quality of water body have significant effect on structure of zooplankton assemblages that can potentially affect the functioning of ecosystem. Seasonal distribution of the population structure of zooplankton in connection with physicochemical parameters Sarkar and Chaudhary (1999). Hence, Zooplankton communities of numerous water bodies have been used as indicators for the status of the ecosystem (Jeppensen et al., 1999; Ramchandra and Solanki, 2007) and related with the concentration of total nitrogen, total 
phosphorus, algal biomass and the density and size of individuals (Giselle and Bruce, 2007). The variability observed in the distribution of zooplankton is due to abiotic parameters. In the aquatic ecosystem plankton play a critical role not only in converting plant food to animal food but also serves as source of food for their organisms (Rajashekhar et al., 2010). In the present study indicated that a total of 16 zooplankton species were recorded in the study ponds comprising of 9 rotifera, 3 cladocera and 4 coppepods. Rotifera showed highest number of species and genus Brachionus is dominant group among rotifera. Bharti et al., (2014) reported that the abundance of rotifer species such as Brachionus indicates nutrient rich water body which may undergo the state of eutrophication. The present preliminary study conducted that the various zooplankton composition. Rotifera constitute higher species abundance, the overall diversity index shows eutrophic nature. Further, detailed investigation through regular monthly sampling with more quantitative analysis to conform the exact status of water body is required which would help to conserve the zooplankton diversity and water quality.

\section{References}

APHA, 1985. Standard methods for the examinationofwaterandwastewater $16^{\text {th }} \mathrm{e}$ dition American Public Health association, Washington DC.

Ahamad, V., Parveen, S., Khan, A.A., Kabir, H.A., Mola, H.R.A. and Ganai, A.H. 2011: Zooplankton population in relation to physiochemical factors of the sewage fed pond of Aligarh (U.P) India. Biol. Medic., 3: 336-341.

Ahmad, M.S. and Siddiqui, E.N. 1995: Freshwater diatoms of Darbhanga. J. Fresh. Biol., 7: 41-48.

Alfred, J.R.B., Bricice, S. Issac, M.L., Michael, R.G., Rajendran, M., Royan,
J.P., Sumitra, V. and Wycliffe, J. 1973: A guide to the study of freshwater organisms. J. Madras Univ. Suppl., 1:103-151.

Bharati, G.K., Shinde, S.M., Rane, M.S. 2014: Composition and biodiversity of Rotifer population in Godavari River. Ind. J. Appl. Res., 4 (6): 554-556.

Basawarajeshwari I, Ramakrishna Reddy, Vijaykumar K. 2015 Zooplankton diversity in fresh water reservoir of Yadigir district, Karnataka state int. J. Curr. Inn. Res.

1(1): 19-22.

Choudhary, S. and Singh, D.K. 1999. Zooplankton population of Boosra Lake at Muzaffapur, Bihar. Env. Ecol., 17: $444-448$.

Egborge, A.B.M. 1981. The composition, seasonal variation and the distribution of zooplankton in LakeAsejire, Nigeria. Revue de Zoologie Africaine, 95: 136144.

El-Serafy, S.S., Mageed, A.A. and EL-Enany, H.R. 2009. Impact of food, water on the distribution of zooplankton in the main channel of Lake Nasser, Egypt. J. Egypt. Acad. Soc. Environ. Delop. 10: 121-141.

Epifanio, C.E. and R.W. Garvine R.W. 2001. Larval transport on the Atlantic continental shelf of North America. Estu. Coast. Shelf. Sci., 52: 51-77.

Gaikwad, S.R., Ingle, K.N. and Thorat, S.R. (2008): Study of zooplankton patter and resting egg diversity to recent dried water bodies in north Maharashtra region. J. Env. Biol., 29: 353-356.

Giselle VT and Bruce RF. 2007. Relationships among nitrogen and total phosphorus, algal biomass and zooplankton density in the central Amazonia lakes. Hydrobiologia, 595:177-195.

Guillermo, C. 2009. The use of phytoplankton patterns of diversity for algal bloom 
management. Limnologica, 39: 225227.

Ikpi, G.U., Offem, B.O. and Okey, I.B. 2013: Plankton distribution and diversity in tropical earthen ponds. Env. Nat. Resou. Res., 3 (3): 45-51.

Iloba, K.I. 2002. Vertical distribution of Rotifera in the Ikpoda reservoir in southern Nigeria. Tro. Fres. Bio, 11: 6989.

Jeppensen E, Jensen J P, Sondergaard M and Lauridsen TL, 1999. Trophic dynamics in turbid and Clearwater lakes with special emphasis on the role of zooplankton for water clarity. Hydrobiologia, 408/409:217-231.

Madhusudhana, R.K. and Krishna, P.V. 2013. Seasonal variations in hydrographic status of Interu mangrove swamp of River Krishna estuarine region, Andhra Pradesh, India. Bioinfo Aquatic Ecosystem, 2 (1): 43-50.

Malten, M.A., Paeel, H.W., Rudek, J. 1991. Seeasonal phytoplankton composition, productive and biomassin the Neuse River Estuary, North Carolina. Estur. Coast. Shelf. Sci., 32: 609-623.

Mathivonam, V.P., Vijayan, S., Sabhanayakan and Jayachitra, O. 2007. An assessment of plankton population of Cauvery River with reference to population. J. Env. Biol., 28: 523-526.

Mola, H.R. 2011. Seasonal and Spatial distribution of Brachionus (Pallas, 1966; Eurotatoria: Monogoranta: Brachionidae), a bioindicator of eutrophication in Lake El-Manzalah, Egypt. Biol. Medi., 3: 60-69.

Mukherjee, P. 2011. Stastical analysis of biodiversity of zooplankton population in a filthy Trapa-cum-Fish cultured pond of central India. Int. J. Zool. Res., 1(2): 24-29.

Muylaert, K.S., Declerck, V., Geenens, J.V., Wichelen, H., Deegans, J., Vandekerkhove K.V. and Vyverman,
W. 2003. Zooplankton, phytoplankton and the microbial food web in two turbid and two clear shallow lakes in Belgium. Aquat. Ecol., 37: 137-150.

Narasimha Ramulu, K. and Benarjee, G. 2013. Physicochemical parameters influenced plankton biodiversity and fish abundance - A case study of Nagram tank of Warangal, Andhra Pradesh. Int. J. Life Sci. Biot. Pharma Res., 2(2): 248-260.

Park, K.S. and Shin, H.W. 2007. Studies on phyto-and-zooplankton composition and its relation to fish productivity in a west coast fish pond ecosystem. J. Env. Biol., 28: 415-422.

Pejler, V., 1965. Regional ecological studies of Swedish freshwater zooplankton. Zool. Bidr. Uppsala, 36: 407-515.

Radwan, S., Kowalczyk, C.Z., Podgorski, W. and fall, J. 1973. A contribution to the hydrochemistry of the Leczna and Wlodawa Lake District, Part, III Physical chemical properties. Ann. Univ. Mariae Curie-Sklodowska., C 28: 97-116.

Rajagopal, T. Thangamani, A. and Archunan, G. 2010. Comparison of Physicochemical parameters and phytoplankton species diversity of two perennial ponds to Sattar area, Tamilnadu. J. Env. Biol., 31: 787-794.

Raja, P., Amaranath, A.M., Elangovan, V. and Palanivel, M. 2008. Evaluation of physical and chemical parameters of river Kaveri, Tiruchirapalli Tamil Nadu, India. J. Env. Biol. 29: 765-768.

Rajashekhar, M., VijayaKumar, K. and Praveen, Z. 2010. Seasonal variation of zooplankton community in freshwater reservoir Gulbarga district, Karnataka, South India. Int. J. Syst. Biol., 2: 6-11.

Ramchandra TV and Solanki M, 2007. Ecological Assessement of Lentic Water Bodies of Bangalore. Envis Technical Report: 25. Indian Institute of 
Science, Bangalore.

Rocha, O., Matsumura-Tundisi, Y.T., Espindola, E.L.G., Roche, K.F. and Rietzler, A.C. 1999. Ecological theory applied to reservoir zooplankton, In Tundisi JG, Straskraba M (eds) Theoretical reservoir ecology and its applications. International Institute of Ecology, Brazilian Academy of Sciences. Backhugs publishers, Leiden, Holland, pp. 29-51.

Sarkar SK and Chaudhary B, 1999. Role of some environmental factors on the fluctuations of plankton in a lentic pond at Calcutta.Limnological research in India.Daya publishing house. Pp 108130.

Shaked, Y., Erel, Y. and Sukenik, A. 2004. The biogeochemical cycle of Iren and associated elements in Lake Kinneret. Geochimical ET Cosmochimica Acta, 68: 1439-1451

Shannon, C.E. and Weaver, W. 1949. The mathematical theory of communication. The University of Illinois Press, Urbana, pp.117.

Siddamalayya, N. and Pratima, M. 2008. Impact of domestic sewage on freshwater body. J. Env. Bio, 29: 303308.
Singh, S.P., Pathak, D. and Singh, R. 2002. Hydrobiological studies of two ponds of Satna (M.P), India. Eco. Env.Cons, 8: 289-292.

Smitha, P.G., Byrappa, K. and Ramaswamy, S.N. 2007. Physico-chemical characteristics of water samples of Bantwal Taluk, South-estern Karnataka, India. J. Env. Biol., 28: 591-595.

Sousa W, Jose L, Attayde, Elinez Dasilva Rocha and Eneida Maria EskinaziSantanna, 2008. The response of zooplankton assemblages to variations in the water quality of four man-made lakes in semi-arid northeastern Brazil. J.Planktron Research, 30(6):699- 708.

Tanner, C.C., Craggs, R.J., Sukias, J.P. and Park, J.B. 2005. Comparison of maturation ponds and constructed wet lands as the find stage of advanced ponds system. Water Sci. Technol., 51: 307-314.

Xing, W. and Liu, G. 2011. Iron biogeochemistry and its environmental impact in freshwater lakes. Fresenius Env. Bull. 20(6): 1339-1345.

Welch, P.S. 1984. Limnology methods. McGraw Hill Book Co. Inc. New York.

Wetzel, R.G. 1975. Limnology, W.B. Sauders CO: Philadelphia pp. 743.

\section{How to cite this article:}

Krishna, P.V. and Hemanth Kumar. 2017. Seasonal Variations of Zooplankton Community in Selected Ponds at Lake Kolleru Region of Andhra Pradesh, India. Int.J.Curr.Microbiol.App.Sci. 6(8): 2962-2970. doi: https://doi.org/10.20546/ijcmas.2017.608.355 